\begin{tabular}{|l|l|l|}
\hline \multicolumn{2}{|c|}{ PublisherInfo } \\
\hline \hline PublisherName & $:$ & BioMed Central \\
\hline \hline PublisherLocation & $:$ & London \\
\hline \hline PublisherImprintName & $:$ & BioMed Central \\
\hline \hline
\end{tabular}

\title{
Don't blame the translocations
}

\begin{tabular}{|l|l|l||}
\hline \multicolumn{2}{|c|}{ ArticleInfo } \\
\hline \hline ArticleID & $:$ & 3693 \\
\hline \hline ArticleDOI & $:$ & $10.1186 /$ gb-spotlight-20000602-01 \\
\hline \hline ArticleCitationID & $:$ & spotlight-20000602-01 \\
\hline \hline ArticleSequenceNumber & $:$ & 130 \\
\hline \hline ArticleCategory & $:$ & Research news \\
\hline ArticleFirstPage & $:$ & 1 \\
\hline \hline ArticleLastPage & $:$ & 2 \\
\hline \hline & $:$ & RegistrationDate : 2000-06-02 \\
ArticleHistory & $:$ & OnlineDate $: 2000-06-02$ \\
\hline \hline ArticleCopyright & $:$ & BioMed Central Ltd2000 \\
\hline \hline ArticleGrants & $:$ & \\
\hline \hline ArticleContext & $:$ & 130591111 \\
\hline \hline
\end{tabular}




\section{William Wells}

Email: wells@biotext.com

Chromosomal rearrangements could, in theory, cause speciation by inducing chromosome loss and missegregation after the mating of two recently diverged species. Fischer et al. test this theory in the 25 May Nature and find it wanting (Nature 2000, 405:451-454). They detect translocations by hybridizing probes from each arm and centromere of Saccharomyces cerevisiae chromosomes to chromosome blots from five other Saccharomyces species. The distribution of the ten detected translocations amongst the species indicates that the rate of formation of new translocations is not constant, and translocations are not a necessary part of speciation. Breakpoints occur preferentially in regions with repeated sequences, such as tRNAs and Ty elements.

\section{References}

1. The mismatch repair system contributes to meiotic sterility in an interspecific yeast hybrid.

2. Nature magazine, [http://www.nature.com/nature/] 